\title{
IAMJ
}

INTERNATIONAL

AYURVEDIC

MEDICAL JOURNAL

\section{PREVENTIVE CARE IN OPHTHALMOLOGY - A REVIEW ARTICLE}

\section{Seema Yadav ${ }^{1}$, Hardik Chudasama ${ }^{2}$, Gulab Chand Pamanani ${ }^{3}$, Aparna Sharma ${ }^{4}$}

${ }^{1}$ PG Scholar, Department of Shalakya Tantra, National Institute of Ayurveda, Deemed to be University, Jaipur, Rajasthan,

${ }^{2} \mathrm{Ph} . \mathrm{D}$ Scholar, Department of Kriya Sharir, National Institute of Ayurveda, Deemed to be University, Jaipur, Rajasthan.

${ }^{3}$ Associate Professor, Department of Shalakya Tantra, National Institute of Ayurveda, Deemed to be University, Jaipur, Rajasthan, India

${ }^{4}$ Associate Professor, Department of Shalakya Tantra, National Institute of Ayurveda, Deemed to be University, Jaipur, Rajasthan, India

Corresponding Author: drseema1989@gmail.com

\section{https://doi.org/10.46607/iamj3309112021}

(Published Online: November 2021)

Open Access

(C) International Ayurvedic Medical Journal, India

Article Received: 02/11//2021 - Peer Reviewed: 12/11/2021 - Accepted for Publication: 15/11/2021

\section{Check for updates}

\section{ABSTRACT}

Shalakya Tantra is an important branch in Ayurveda which deals with the diseases of the supraclavicular region. Eyecare is described under "Shalakya Tantra". The eye is the most important and sensitive of five sense organs in the human body. Ayurveda also gives prime importance to the eye and primarily aim at the prevention of disease and promotion of positive health. Some of the faulty lifestyle exposures like sedentary habits, smoking, alcohol consumption, fat, sugar-rich diet, junk food, high carbohydrate food etc are notably associated with the risk of developing eye diseases. Association of eye diseases with Dinacharya, Ritucharya, Aahara-Vihara, Mind, Occupation, and Aging process are also important. Factors like continuous hours spent reading, watching TV, using mobile and working on computers take their toll on eye health. Ayurveda possesses vivid information about the lifestyle leading to healthy living and also the preventive strategies in general. For eye diseases, a few daily regimens like Aschyotana (eye drops), Anjana (Collyrium), Nasya (nasal application of drugs), Abhyanga (oil mas- 
sage) are promoted as high-end measures for the maintenance of eye health, Various Netra vyayama (eye exercises), Yoga, Pranayama and Satkriya (Neti, Trataka etc) are also an effective therapy for healing of eye disorders.

Keywords: Dincharya, Ritucharya, Aschyotana, Anjana, Padabhyanga

\section{INTRODUCTION}

Ayurveda is the most ancient system of medicine. "Swasthasya swasthya rakshanam aturasya vikara prasamanm cha" "explains the aim and objective of Ayurveda, to preserve the health of a healthy person and to cure the diseased one. The eye is considered the most important sense organ in Ayurveda. Eyecare is covered under the "Shalakya Tantra," one of eight branches of Astanga Ayurveda ${ }^{2}$. Eyes are the windows to the mind. Mind motivates the sensory faculties to perceive their respective objects.

manah purssarani indriyani arthagrahana samarthaani bhavanti $\left.\right|^{3}$ (C.su. 8/7)

Imagination is perfect, sight is the good diversion of mind Vision is a mental interpretation process. The picture which the mind sees is not the impression on the retina, but a mental interpretation of it. Vision depends on the mind is one of the inhibitory factors of vision.

If a person is endowed with all other sensory faculties, strength, beautiful appearance etc. but without eyesight, he will be as useless as an insect.

Chakshooraksjayam sarvakalam manushyairyatnah kartavyo jeevite yavadichchha|

Vyartho lokoyam tulya ratrinidavaanaam | pumsam mandhanam vidhyamaanepi vitte $\|$

(A.S.U. 16/29)

Efforts should be made by everyone to protect one's eyesight regularly. Even if a blind person is wealthy, day and night are equal to him, and the entire world appears to be pointless.

Many eye disorders have been caused by changes in lifestyle, pollution, excessive use of computers and mobile phones, inconsistent sleeping patterns, inappropriate daily and seasonal routines, physical inactivity, incorrect body posture and a disrupted biological clock.

Various Hetu and Pathya-Apathya related to NetraVikaras are also mentioned in detail by Acharya
Sushruta, such as Ushnabhitaptasya Jalapraveshat (immersion in cold water immediately after being exposed to heat or sun), Swapana Viparyayat (abnormal sleeping habits such as day sleep and alert at night), Klesha (Pain, Anguish, Distress and Trouble), Vegavinigraha (Suppression of urges), Dhoomanishevanat (Excessive exposure to smoke and other pollutants) and Sukshmanireekshanat (watching minute objects for long duration $)^{4}$. Glaucoma, Cataract, Computer vision syndrome, Dry eye syndrome, Age-related macular degeneration, Diabetic retinopathy, Hypertensive retinopathy and other diseases may develop as a result of poor lifestyle choices. Dincharya, Ritucharya, Yoga, Aasana, Satkriya, Kriyakalpa, Sadvritta, Chakshusya Rasayana medicines, and Pathya Aahara-Vihara are some of the Ayurvedic complete remedies to prevent eye problems.

\section{SROTAS LINKED TO EYES-}

Though all the channels are linked with the eyes, any damage to Annavaha and Raktavaha srotas will immediately lead to visual loss 5 .

Thus, the eye has intricated connections with Srotas of the body. Hence, due care should be taken to assess their status while analysing and treating eye diseases.

Netra Roga Hetu ${ }^{6}$ (General Causes) -

1. Adi bala-Genetic

2. Janma bala-Congenital

3. Dosha bala-Constitutional

4. Sanghata bala-Traumatic

5. Kala bala -Seasonal

6. Daiva bala-Infections and Spiritual

7. Swabhava bala-Natural

The basic principle of Ayurveda is based on the Tridosha (Vata, Pitta, and Kapha), which is responsible for optimal body function and, when vitiated, leads to disease. The role of dosha is different from 
organ to organ, so etiological factors for vitiation of dosha are also different for different organs. In the eye Alochak Pitta ${ }^{7}$ is considered as a responsible factor for visual perception i.e., of all Mahabhuta; Tejas Mahabhuta dominates in the composition of eyes. So, the eyes are especially susceptible to Kapha. That's the way the factors which are vitiating Pitta or Kapha will lead to eye diseases.

\section{Samprapti (Pathogenesis of Eye Diseases)}

In Ayurveda, the Acharya described a generalized Samprapti for all eye diseases. The vitiated dosha will course through the vessels and reach upwards, to produce diseases in different parts of the eye. Siranusaribhirdoshairvigunairudhrvamaagataih ||
Jayante netrabhageshu rogah paramdarunah \| (Su.Ut. 1/20-21)

The intake of 'Achakshushya Ahara and Vihara' and Pitta Prakopaka, in particular, will increase the Mala in the head. They will be pathologically lodged in Vartma, Sandhi, Sita, Krishna, Dristi or in all these parts to produce diseases.

Sarvaroganodanoktairahitaih kupita malah | achakshushyairvisheshena prayah pittanusarinah| Sirabhirudhvam prasuta netravayavamashritah | vartm sandhim sitam krushnam drushtim va sarvamkshi vaa

rogan kuryuh.

(A.S.Ut.

\section{Flow chart of Samprapti-}

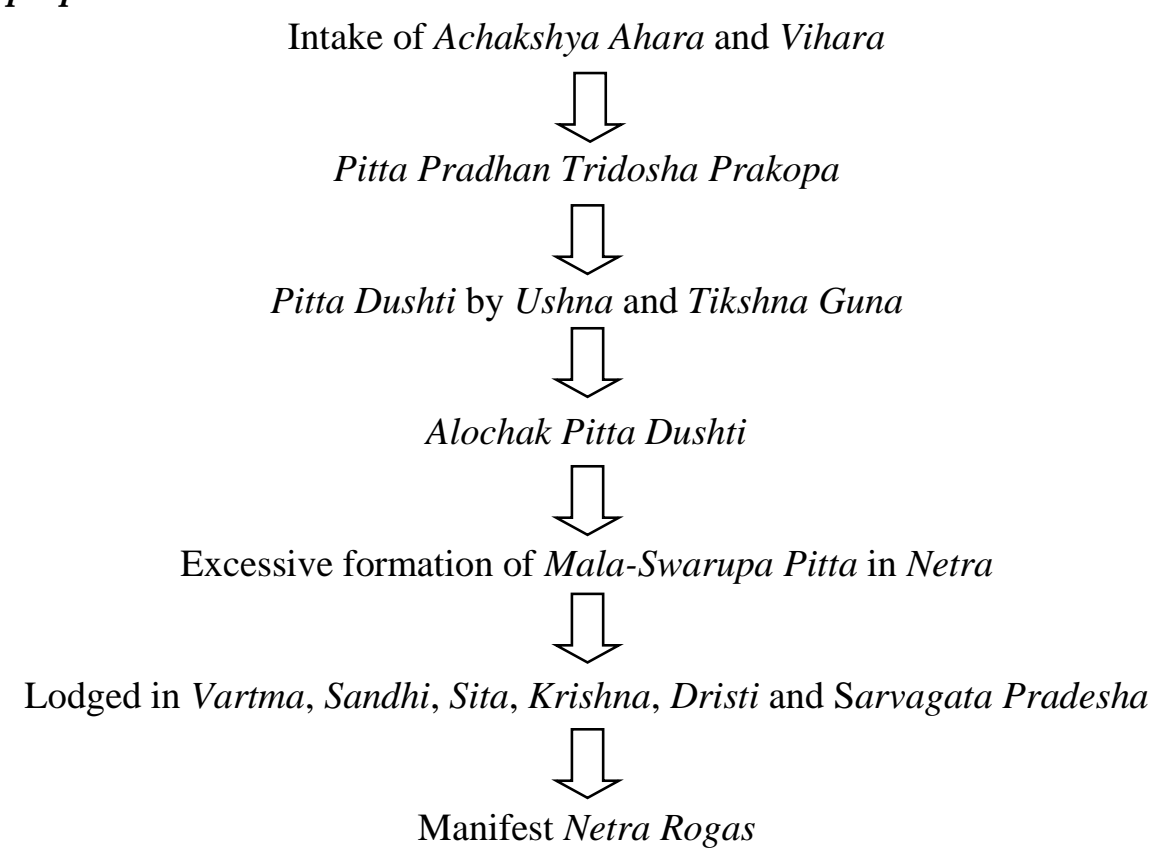

Pathophysiology -

Diet and exercise regimens affect the body and are influenced by Agni (the metabolic fire). In Ayurveda, the concept of Agni refers to the metabolism that occurs at the tissue, molecular, and cellular levels. Unhealthy eating habits and regimes alter metabolism, resulting in lower-quality by-products that enter the circulation and reach the eye, and that obstruct the normal anatomical and physiological functioning of the eyes. So, when Agni is normal health is normal. Materials and Methods-

A comprehensive study was done on depictions related to various preventive eye cares in Ayurveda. Descriptions were gathered from different Ayurvedic Samhitas, and the latest research papers identified with it were looked online from logical destinations viz. Pubmed, Google researcher, web of science by 
utilizing catchphrases like eye care, prevention of eye disease and role of Ayurveda in visual health.

\section{Dinacharya $^{8}$ (Daily Regimen)}

In ancient literature such as the Charak Samhita Sutrasthan Swatha Chatuska, Sushruta Samhita Chikitshasthan 24th chapter, and Astanghrudaya Uttarsthan 13th chapter, Dinacharya on the maintenance of eye health is eloquently addressed. Acharya Shushruta recommends starting the day with Netra Prakshalana, but Acharya Charak suggests Anjana.

a) Netra-prakshalana9 (Washing of eyes): A cold water decoction of Lodhra (Symplocos racemosa) or Amalaki (Emblica Officinalis) should be used. It helps in the cleansing of the eyes by eliminating dust and foreign materials, allowing for clear vision. Decoction of Triphla, Lodhra, Madhuyasti is used as an eyewash in various refractive errors like Timira, Red eye, Pain in the eye etc.

b) Anjana ${ }^{10}$ (collyrium)- Daily usage of Souviranjana (antimony sulphide collyrium) is good for the eyes and using Rasanjana (extract of Berberis aristata) every 5 th or 7 th day helps to remove Kapha Dosha from the eyes in the form of tears, keeping the eyes clean. Anjana is applied from the inner to the outer canthus. It cleanses the human eyes, causing them to shine like a bright moon in a clear sky. Anjana's action is linked to dissolving and emptying the stored vitiated Kapha. It dilates blood vessels, enhances blood flow, and keeps Netrasrotas in good shape. As a result, practising Anjana as Dinacharya regularly is the finest simple ophthalmic treatment for preventing eye disorders.

c) Nasya ${ }^{11}$ (Nasal installation): The nose is a channel to the head (Shira). Nasya stimulates Sringataka Marma, which nourishes all sense organs, including Netra (seat of all the centres of vision, smell, hearing and taste). Nasya cleans the Shiro-srotas and always has an action on the Srotas (channels). The accumulation of vitiated Kapha in the Srotas of the eye can be avoided by using Pratimarsh Nasya daily. Anutaila as Pratimarsh Nasya 2 drops in each nostril im- proves vision and keeps the strength of other sense organs healthy and free of flaws.

d) Nidra $^{12}$ (sleep): During sleep eyes retain functional capacity due to the complete rest of the eyes. Sleep is a key part of a healthy lifestyle. Ayurveda mentions that irregular sleep and suppression of urge of sleep are the causes of eye disorders. Therefore, to maintain eye health the proper sleep is mandatory.

e) Shiro-Abhayanga ${ }^{13}$ (Oiling massage on Head) The application of medicinal oil to the head, particularly the Murdha region, daily strengthens the eyes and serves as a preventative step for sense organ problems. It performs the function of Drishti Prasadan. The medicated oil is applied to the scalp reaches the brain. The optic nerve, which terminates in the retina (Dristi-Patalam), is a direct extension of the brain stem. As a result, the oil was applied to the head. So, according to a person's "Prakriti," daily use of medicinal oil is a preventive step for eye problems.

f) Sheetodak Shira Snana ${ }^{14}$ - Hair and eyes may be adversely affected by using hot water for a head wash. As a result, head washing should be done with cold water.

g) Padabhayanga ${ }^{15}$ (Oil massage on feet) - Regular massage of feet is advised because it is assumed that in the centre of feet (soles) 2 Siras are situated which are greatly connected to the eyes. These are vitiated by the accumulation of debris, attack, trauma from stone or foreign particles, and result in eye disorders. Medicines applied over the feet, feet massage, external application of oil etc. transmit the benefit to the eyes. Hence feet should be kept clean, healthy and away from the heat by using footwear, washing them well and massaging with oil. Padabhyanga affects both Sthanik Dosha (local factors) and Sarvadehik Dosha (general factors), according to various Ayurvedic texts. Regular foot massage improves visual clarity. Acharya Charak and Vagbhatta have described it as Dristi-prasadaka (for clear and bright vision). Acharya Sushruta 
has also described it as Chakshushya (beneficial for eyes).

h) Pada-prakshalan ${ }^{16}$ - (Feet washing)- Washing and cleaning the feet, according to Acharya Sushrut, is considered as Chakshushya (beneficial for eyes).

i) Netra - Tarpan ${ }^{17}$ - It is a restorative Ayurveda treatment that baths the entire eye socket in a pool of lukewarm Ghrita, this helps to nourish dry eyes, cleanse and soothe itchy eyes, Ghrita cools the Pitta and lubricates Vata Dosha. It is recommended for many ocular disorders. Moreover, it provides nourishment to ocular tissues.

j) Vegadharana ${ }^{18}$ (Suppression of Natural Urges)- Charak has mentioned Nidra (sleep) and Baspa vega (Suppression of tear urge) cause heaviness in eyes and various diseases of eye respectively. It is quite evident that in modern age lifestyle, people used to suppress natural urge due to various reasons like busy work schedule, frequent travelling and many other reasons.

k) Dhumpana ${ }^{19}$ - (Medicated smoking)- It cures pain in the eyes and strengthens sense organs and help in better vision.

1) Usha-Jalpana or Nasa-Jalapana ${ }^{20}$ (Intake of water through mouth or nose) - Daily intake of water through mouth or nose in the morning ensures good vision.

m) Padatra Dharana ${ }^{21}$ - (Use of footwear) - Footwear aids in maintaining optical acuity.

n) Kaval and Gandoosh ${ }^{22}$. The special methods of medication in which the medicines are applied in the mouth in the form of liquid and semi-solid are called Kaval and Gandoosh. In Kaval, medicine is filled in the mouth to such an extent that we can shake it. The medicine is in liquid form so that while shaking the medicine reaches all parts of the oral cavity. The ophthalmic branch of the facial artery lies along the cheek. Medicine may get nourished, stimulated, evacuated or maintained by the medicinal value of the drugs used for Kaval. In Gandoosha the same function can be explained due to an increase in permeability of vessels, which in turn facilitates more absorption of medicines as well the nerve endings of the oral cavity stimulated and brings reflex action in the eyes.

o) Mukha lepa ${ }^{23}$ - Mukhalepa is the application of medications to the face in the form of a poultice. Doshahara, Vishahara, and Varnakara are the three varieties of Mukhalepa. The facial artery, facial nerve, and trigeminal nerve run along the cheek, with branches leading to the eyes. As a result, the Mukha-therapeutic Lepa's efficacy affects the eye

p) Yoga evam Aasana ${ }^{24}$ - Shirshasana and Suryanamaskara are two significant Asanas that have been shown to benefit the eyes. These Asanas enhance circulation to the blood vessels and capillaries, relax the eyes, and are said to improve vision over time. Matsya Asana also provides eye relaxation and helps to prevent refractive errors and other issues.

q) Satkriyas ${ }^{25}$ - Trataka and Neti Kriya may aid in eyesight improvement and eye health maintenance. Accepting techniques such as Trataka and Neti Kriya helps to improve vision and prevent eye problems, according to Hathayoga Pradipika and Gheranda Samhita.

r) Eye exercises- Up-down, sideways (right-left), and rotational (clockwise-anticlockwise) eye movements, followed by palming, are particularly helpful in reducing refractive errors.

s) Snana $^{26}$ (Bath): A cold water head bath refreshes all sense organs and improves eyesight, but a hot water head bath has a deleterious effect on the eyes.

* Ritucharya ${ }^{27}$ (Seasonal regime) - Due to climatic changes, many changes occur in the physiology of the eye which may lead to many diseases. When one Ritu is completed and another one is commenced, the changes in atmosphere trigger off many ailments. For getting rid out of these, Acharya has mentioned Ritu-charya under the heading of Ritu Sandhi. One should follow these for the prevention of Netra Roga in various Ritu.

* Chakshusya Rasayana drugs- Triphala, Honey, and Ghrita should be drunk regularly at night, 
according to Acharya Vagbhatta, for eyesight strengthening. The correct application of Chakshushya and Rasayana dravyas will help to maintain eyes health. The use of Yastimadhu, Ghrita and Triphala act as Rasayana.

(1) Jivaneya drug Yasthimadhu (Ch.Su.4/11)

(2) Dronipravesikrasayan-Ch. Chi.1-4/7

(3) Suvarna (Gold) - Su.Su. 46/325

(4) Bijaksaradi yoga-Su.Chi.27/12

(5) Vidanga Tandula Yoga (2 $\left.{ }^{\text {nd }}\right)$ Su.Chi.27/8

(6) Triphala Rasayana - A.S.Su. 12/47

(7) Mustadi yapana Vasti A.S.Ka.5/11
(8) Tuvarak Taila - A.S.U.49/55

\section{Modern view of eye care and nutrition-}

There are more than fifty nutrients identified for keeping the human body healthy, including micronutrients and minerals. Many studies have been conducted that show a link between eye care and nutrition. The most significant micronutrients and minerals for eye health include vitamins A, C, E, B, carotenoids, zinc, selenium, copper, chromium, iodine, magnesium, potassium, essential fatty acids, and omega-3 fatty acids.

Table 1: Eyecare with Vitamins and Minerals ${ }^{28}$

\begin{tabular}{|l|l|l|}
\hline S.NO & Nutrients & Food Item \\
\hline 1 & Vitamins & $\begin{array}{l}\text { Sweet potatoes, Carrots, Dried apricots, Bell peppers, Dark Leafy greens, Fish, Liver and } \\
\text { tropical fruits }\end{array}$ \\
\hline 2 & Vitamin B & Spinach, Parsley, asparagus, broccoli, turnip and mustard green, calf's liver \\
\hline 3 & Vitamin C & Bell peppers, Amalaki, Kiwi fruit, broccoli, berries, citrus fruits, tomatoes, Peas, papaya \\
\hline 4 & Vitamin E & $\begin{array}{l}\text { Spinach, Almond, sunflower seed, avocado, Shellfish, Fish, Olive, Pumpkin, peanuts, aspara- } \\
\text { gus }\end{array}$ \\
\hline Minerals & Zinc & $\begin{array}{l}\text { Oysters, red meat, wheat gram, spinach, pumpkin seeds, Cashew nuts, coco powder, white } \\
\text { mushroom, chicken }\end{array}$ \\
\hline 2 & Selenium & Brazil nuts, oysters, tuna fish, wheat bread, sunflower seeds, pork \\
\hline 3 & Copper & Seafood, meat, egg yolk, soya bean, mushroom, radish, nut \\
\hline 4 & Iodine & Dried seaweed, codfish, yogurt, tuna fish, egg, strawberry, potato \\
\hline 5 & Omega 3 & Flaxseed oil, fish oil, chia seeds, walnuts, caviar, curd, canned fish \\
\hline 6 & $\begin{array}{l}\text { Gamma } \\
\text { Acid }\end{array}$ & Starflower oil, hemp oil, borage oil \\
\hline
\end{tabular}

Table 2: Pathya and Apathya in Netra Roga ${ }^{29}$

\begin{tabular}{|c|c|c|c|}
\hline S. No & Food/activities & Pathya (Wholesome) & Apathya (unwholesome) \\
\hline \multicolumn{4}{|c|}{ Pathya and Apathya in Ahara } \\
\hline 1 & Shukadhanya & $\begin{array}{l}\text { Lohitaksshali (red variety of rice), } \\
\text { Shashtik, Yava (Barley) }\end{array}$ & Germinated cereals / Sprouts \\
\hline 2 & Shimbidhanya & $\begin{array}{l}\text { Mudga (Green gram), Vanya Kulattha } \\
\text { (Dolichos biflorus) }\end{array}$ & $\begin{array}{l}\text { Kulattha (Horse gram), Masha } \\
\text { (Black gram) }\end{array}$ \\
\hline 3 & Mamsa (Meat) & $\begin{array}{l}\text { The flesh of bird, tortoise flesh, lobster, } \\
\text { peacock }\end{array}$ & $\begin{array}{l}\text { Matsya (Fish), the flesh of animals } \\
\text { living in semi-arid tropics }\end{array}$ \\
\hline 4 & $\begin{array}{l}\text { Shaka varga (Green vegeta- } \\
\text { bles) }\end{array}$ & $\begin{array}{l}\text { Jeevanti (Leptadenia reticulate), } \\
\text { karvellaka (Bitter gourd), solanum } \\
\text { nigrum, Aloe vera, unripe banana and } \\
\text { reddish, pointed gourd, Allium sativum }\end{array}$ & $\begin{array}{l}\text { Kalingakapatra saka (Holarrhaena } \\
\text { antidysentrica) }\end{array}$ \\
\hline 5 & Phala varga (Fruits) & (Pomegranate), & Citrullus lanatus \\
\hline
\end{tabular}




\begin{tabular}{|c|c|c|c|}
\hline & & $\begin{array}{l}\text { (Grapes), Amalaki (Emblica Offici- } \\
\text { nalis), Vibhitaki (Terminalia belerica), } \\
\text { Abhaya (Terminalia Chebula) }\end{array}$ & \\
\hline 6 & $\begin{array}{l}\text { Dugdha Varga (Milk and } \\
\text { Curd) }\end{array}$ & $\begin{array}{l}\text { Nari dugdha (Human milk), Cow milk, } \\
\text { Hastini (Elephant) milk, Ashwa dadhi } \\
\text { (Curd prepared out from horse milk) }\end{array}$ & $\begin{array}{l}\text { Milk gotten from morning time, Go } \\
\text { dadhi }\end{array}$ \\
\hline 7 & Ghrita & $\begin{array}{l}\text { Ghee prepared from cow's, goat and } \\
\text { human milk, }\end{array}$ & ----------- \\
\hline 8 & Oils & Tila taila (sesamum indicum) & $\begin{array}{l}\text { Atasi (Linum usitatisimum), Kusum- } \\
\text { bha taila }\end{array}$ \\
\hline 9 & Kanda (Roots) & Adarak (Zingiber officinalis) & -------- \\
\hline 10 & $\begin{array}{l}\text { Ikshu Vikar (Derivatives of } \\
\text { Sugarcane etc..) }\end{array}$ & Sita (Sugar) & $\begin{array}{l}\text { Phanita (confectionary in thick liq- } \\
\text { uid) }\end{array}$ \\
\hline 11 & Lavana & Rock salt & Other salt \\
\hline 12 & Seeds & $\begin{array}{l}\text { Katak (Strychnos potatorum), } \\
\text { Chakshushya (Casia absus), Shobhanja- } \\
\text { na (Moringa Olifera) }\end{array}$ & $\begin{array}{l}\text { Sprouted paddy seed, Tilkut } \\
\text { (Sesamum indicum) }\end{array}$ \\
\hline 13 & Ahar upyogi (Processed food) & $\begin{array}{l}\text { Peya, Vilepi, Yusha (Rice gruelling } \\
\text { preparation) }\end{array}$ & $\begin{array}{l}\text { Shukta (Vinegar), Aranala (Sour } \\
\text { gruel) }\end{array}$ \\
\hline 14 & Rasa & Sweet, Sita (Sugar) & $\begin{array}{l}\text { Amla, Lavana, Katu, Kshara (Alka- } \\
\text { li), Sour items like pickles in excess }\end{array}$ \\
\hline 15 & Loha varga & Swarna (Gold), Kamsya (Bronze) & -------- \\
\hline 16 & Ratna varga & $\begin{array}{l}\text { Mukta (Pearl), Vidruma (Coral), Vajra } \\
\text { (Diamond), Vaidurya (Cats eye), } \\
\text { Sphatika (Alum) }\end{array}$ & -------- \\
\hline 17 & $\begin{array}{l}\text { Sugandhi dravya (Aromatic } \\
\text { drugs) }\end{array}$ & Chandan (Sandal), Karpura (Camphor) & Tambula \\
\hline \multicolumn{4}{|c|}{ Pathya and Apathya in vihar } \\
\hline 18 & Habits & ---------- & $\begin{array}{l}\text { Atimaithuna (Excessive sex), Vata } \\
\text { vit mutra, nidra vega avarodha } \\
\text { (withholding the urge of flatus, fae- } \\
\text { ces, urine and sleep), Ratri jagarana } \\
\text { (Waking till late night), Danta } \\
\text { vigharshana (Brushing teeth with } \\
\text { pressure), Surya vilokana, Sukshma } \\
\text { ekshana (Viewing sun and minute } \\
\text { things directly), Chardi Nigrahana } \\
\text { (Withholding the urge of vomiting), } \\
\text { Avak shira shayana (Sleeping } \\
\text { Prone), Ucchita Shira Shyana (Using } \\
\text { High pillow), Ati sheegra yanam } \\
\text { (riding fast), Adhyayana during yana } \\
\text { (Reading during travelling) }\end{array}$ \\
\hline 19 & $\begin{array}{l}\text { Manasika Bhava (Psychologi- } \\
\text { cal traits) }\end{array}$ & Mano- nivrutti (Self Control) & $\begin{array}{l}\text { Krodha (Anger), shoka (sorrow), } \\
\text { Ashrupata (Continuous crying), Ab- } \\
\text { highata (trauma), Bashpa Nigraha } \\
\text { (withholding tears) }\end{array}$ \\
\hline
\end{tabular}




\section{DISCUSSION}

Ayurveda is a philosophy of life that explains well the maintenance of the eye. Human eyes are extremely delicate organs that should be free from stress, near watching activities for a long time and living in a polluted environment. But due to the present way of lifestyle, our eyes have to bear a lot of stress and limited resistance against eye tissue. As a result, the person suffers from refractive errors, cataracts and other eye problems. Apart from treatment modalities, Ayurveda believes in daily and seasonal regimens, PathyaApthya, Yoga, Asanas and Pranayam as a supportive measure for the well-being of eyes. Above all promotive care and restoring measures are described in the classical text of Ayurveda, neutralizing the effect of today's stressed lifestyle over eyes, strengthening eye muscles, making lens fibre elastic etc. The eye promotive regimen delays the degenerative process in the eye. Once a permanent mechanical change develops in the shape of an eyeball, then it is not possible to reverse the change. Therefore, persons should daily follow a seasonal regime, proper dietary habits like taking balanced healthy diet which contains plenty of green leafy vegetables, fresh fruits and animal food product, eye exercise, Yoga Pranayam and Shatkriya for the preventive and curative aspect of eye diseases.

\section{CONCLUSION}

The adoption of a contemporary lifestyle had an impact on ocular health and cause misery in human society. Ayurveda offers a light of hope for resolving these issues. A healthy lifestyle involving good daily routine, dietary habits and avoidance of causative factors, Aschyotana, Anjana, Nasya, Abhyanga, Various Netra Vyayam, Yoga, Pranayama, and Satkriya can benefit eye health.

\section{REFERENCES}

1. Agnivesh, Charak, Dhrudhabala, Charak samhita in Ayurveda dipika commentary of chakrapani data edited by Vaidhya jadavaji trikam Ji acharya, arthedashamahamuliyadhyaya, Varanasi, Chaukhamba Surbharati publication; 2016. P. 187
2. Susruta, Susruta Samhita, Sanskrit Commentary by Shri Dalhanacarya, Nibandhasangraha, edited by Vaidya. Jadavji Trikamaji Acarya, Vedotpatti adhyaya, Varanasi, Chaukhamba Surbharati publication; 2018. P. 3

3. Agnivesh, Charak, Dhrudhabala, Charak samhita in ayurveda dipika commentary of chakrapani data edited by Vaidhya jadavaji trikam $\mathrm{Ji}$ acharya, indriyopkramaniyadhyaya, Varanasi, Chaukhamba Surbharati publication; 2016. P. 56

4. Susruta, Susruta Samhita, Sanskrit Commentary by Shri Dalhanacarya, Nibandhasangraha, edited by Vaidya. Jadavji Trikamaji Acarya, aupadravikam adhyaya, Varanasi, Chaukhamba Surbharati publication; 2018. P. 597

5. Susruta, Susruta Samhita, Sanskrit Commentary by Shri Dalhanacarya, Nibandhasangraha, edited by Vaidya. Jadavji Trikamaji Acarya, dhamanivyakaranashariram, Varanasi, Chaukhamba Surbharati publication; 2018. P. 386

6. Susruta, Susruta Samhita, Sanskrit Commentary by Shri Dalhanacarya, Nibandhasangraha, edited by Vaidya. Jadavji Trikamaji Acarya, vyadhisamudeshiyadhyaya, Varanasi, Chaukhamba Surbharati publication; 2018. P. 113-14

7. Agnivesh, Charak, Dhrudhabala, Charak samhita in ayurveda dipika commentary of chakrapani data edited by Vaidhya jadavaji trikam Ji acharya, matrashitiyadhyaya, Varanasi, Chaukhamba Surbharati publication; 2016. P. 38-39

8. Susruta, Susruta Samhita, Sanskrit Commentary by Shri Dalhanacarya, Nibandhasangraha, edited by Vaidya. Jadavji Trikamaji Acarya, anagatbadhapratishedneya, Varanasi, Chaukhamba Surbharati publication; 2018. P. 487

9. Susruta, Susruta Samhita, Sanskrit Commentary by Shri Dalhanacarya, Nibandhasangraha, edited by Vaidya. Jadavji Trikamaji Acarya, anagatbadhapratishedneya, Varanasi, Chaukhamba Surbharati publication; 2018. P. 487

10. Agnivesh, Charak, Dhrudhabala, Charak samhita in Ayurveda dipika commentary of chakrapani data edited by Vaidhya jadavaji trikam Ji acharya, matrashitiyadhyaya, Varanasi, Chaukhamba Surbharati publication; 2016. P. 38-39

11. Agnivesh, Charak, Dhrudhabala, Charak samhita in Ayurveda dipika commentary of chakrapani data edited by Vaidhya jadavaji trikam Ji acharya, mat- 
rashitiyadhyaya, Varanasi, Chaukhamba Surbharati publication; 2016. P. 41

12. Agnivesh, Charak, Dhrudhabala, Charak samhita in Ayurveda Dipika commentary of chakrapani data edited by Vaidhya jadavaji trikam Ji acharya, astaunindatiyadhyaya, Varanasi, Chaukhamba Surbharati publication; 2016. P. 118

13. Agnivesh, Charak, Dhrudhabala, Charak samhita in Ayurveda dipika commentary of chakrapani data edited by Vaidhya jadavaji trikam Ji acharya, matrashitiyadhyaya, Varanasi, Chaukhamba Surbharati publication; 2016. P. 42

14. Susruta, Susruta Samhita, Sanskrit Commentary by Shri Dalhanacarya, Nibandhasangraha, edited by Vaidya. Jadavji Trikamaji Acarya, anagatbadhapratishedneya, Varanasi, Chaukhamba Surbharati publication; 2018. P. 489

15. Agnivesh, Charak, Dhrudhabala, Charak Samhita in Ayurveda dipika commentary of chakrapani data edited by Vaidhya jadavaji trikam Ji acharya, matrashitiyadhyaya, Varanasi, Chaukhamba Surbharati publication; 2016. P. 42

16. Susruta, Susruta Samhita, Sanskrit Commentary by Shri Dalhanacarya, Nibandhasangraha, edited by Vaidya. Jadavji Trikamaji Acarya, anagatbadhapratishedneya, Varanasi, Chaukhamba Surbharati publication; 2018. P. 490

17. Susruta, Susruta Samhita, Sanskrit Commentary by Shri Dalhanacarya, Nibandhasangraha, edited by Vaidya. Jadavji Trikamaji Acarya, anagatbadhapratishedneya, Varanasi, Chaukhamba Surbharati publication; 2018. P. 490

18. Agnivesh, Charak, Dhrudhabala, Charak samhita in ayurveda dipika commentary of chakrapani data edited by Vaidhya jadavaji trikam Ji acharya, nvegandharaniyadhyaya, Varanasi, Chaukhamba Surbharati publication; 2016. P. 49-50

19. Agnivesh, Charak, Dhrudhabala, Charak samhita in ayurveda dipika commentary of chakrapani data edited by Vaidhya jadavaji trikam Ji acharya, matrashitiyadhyaya, Varanasi, Chaukhamba Surbharati publication; 2016. P. 40
20. Bhavaprakasha by acharya bhav mishra with English translation by sitaram B, $1^{\text {st }}$ edition, Chaukhambha oriantalia, Varanasi, $1^{\text {st }}$ edition, 2006, poorvakhanda, chapter no 5, shlok no 317

21. Agnivesh, Charak, Dhrudhabala, Charak Samhita in Ayurveda dipika commentary of chakrapani data edited by Vaidhya jadavaji trikam Ji acharya, matrashitiyadhyaya, Varanasi, Chaukhamba Surbharati publication; 2016. P. 43

22. Agnivesh, Charak, Dhrudhabala, Charak samhita in ayurveda dipika commentary of chakrapani data edited by Vaidhya jadavaji trikam Ji acharya, matrashitiyadhyaya, Varanasi, Chaukhamba Surbharati publication; 2016. P. 42

23. Susruta, Susruta Samhita, Sanskrit Commentary by Shri Dalhanacarya, Nibandhasangraha, edited by Vaidya. Jadavji Trikamaji Acarya, anagatbadhapratishedneya, Varanasi, Chaukhamba Surbharati publication; 2018. P. 490

24. Hathayoga oradipika 2 updesha

25. Gherand samhita.1 updesha. 55 Tratak kriya

26. Susruta, Susruta Samhita, Sanskrit Commentary by Shri Dalhanacarya, Nibandhasangraha, edited by Vaidya. Jadavji Trikamaji Acarya, anagatbadhapratishedneya, Varanasi, Chaukhamba Surbharati publication; 2018. P. 490

27. Agnivesh, Charak, Dhrudhabala, Charak samhita in ayurveda dipika commentary of chakrapani data edited by Vaidhya jadavaji trikam ji acharya, tasyashitiyadhyaya, Varanasi, Chaukhamba Surbharati publication; 2016. P. 45

28. Surangi K.G., Shamsa Fiaz. Ayurveda and Modern perceptive on eye care and Nutrition. J Biol. sci. opin 2016; 4 (2): P. 55-58

29. Prof. Shashtri rajeshwar data, Bhaishajya ratnavali of shri Govind ds vidhyatini, Hindi commentary, Chaukhamba prakashan. Ed. Re print 2012. 64, verse 276 284. P.1016-1017

\section{Source of Support: Nil \\ Conflict of Interest: None Declared}

How to cite this URL: Seema Yadav et al: Preventive Care In Ophthalmology - A Review Article. International Ayurvedic Medical Journal \{online\} 2021 \{cited November 2021\} Available from: http://www.iamj.in/posts/images/upload/2850_2858.pdf 